\title{
Histopathological Evaluation of Root Canal Filling Materials for Primary Teeth
}

\author{
Léa Assed Bezerra da SILVA ${ }^{1}$ \\ Mário Roberto LEONARDO ${ }^{1}$ \\ Daniela S. B. de OLIVEIRA ${ }^{1}$ \\ Raquel Assed Bezerra da SILVA ${ }^{1}$ \\ Alexandra Mussolino de QUEIROZ ${ }^{1}$ \\ Patrícia Gatón HERNÁNDEZ ${ }^{2}$ \\ Paulo NELSON-FILHO ${ }^{1}$ \\ ${ }^{1}$ Department of Pediatric Clinics, Preventive and Community Dentistry, Ribeirão Preto Dental School, \\ University of São Paulo, Ribeirão Preto, São Paulo, Brazil \\ ${ }^{2}$ Department of Pediatric Dentistry, University of Barcelona and International University of Catalunia, Spain
}

\begin{abstract}
This study aimed to assess the response of apical and periapical tissues of dogs' teeth after root canal filling with different materials. Forty roots from dogs' premolars were prepared biomechanically and assigned to 4 groups filled with: Group I: commercial calcium hydroxide and polyethylene glycol-based paste $\left(\mathrm{Calen}^{\circledR}\right)$ thickened with zinc oxide; Group II: paste composed of iodoform, Rifocort ${ }^{\circledR}$ and camphorated paramonochlorophenol; Group III: zinc oxide-eugenol cement; Group IV: sterile saline. After 30 days, the samples were subjected to histological processing. The histopathological findings revealed that in Groups I and IV the apical and periapical regions exhibited normal appearance, with large number of fibers and cells and no resorption of mineralized tissues. In Group II, mild inflammatory infiltrate and mild edema were observed, with discrete fibrogenesis and bone resorption. Group III showed altered periapical region and thickened periodontal ligament with presence of inflammatory cells and edema. It may be concluded that the Calen paste thickened with zinc oxide yielded the best tissue response, being the most indicated material for root canal filling of primary teeth with pulp vitality.
\end{abstract}

Key Words: Endodontics, primary teeth, biocompatibility, dental cement, filling.

\section{INTRODUCTION}

Root canal treatment of primary teeth remains a controversial subject in Pediatric Dentistry, and a variety of materials, techniques and treatment protocols have been proposed (1-3) for teeth with both necrotic and vital pulp $(2,4)$.

The success of endodontic therapy relies directly on the accurate accomplishment of all operative procedures, strict compliance with the specific treatment guidelines, and the choice for biocompatible materials. In addition, the filling material must fulfill the accepted triad of treatment goals, namely removal of diseased tissue, elimination or reduction of bacteria, and preven- tion of canal reinfection. The filling material must be biocompatible and protected with a well-sealed coronal restoration.

Several materials have been proposed for the obturation of root canals of primary teeth and, although no single material fulfills all requirements of an ideal endodontic paste filler (1), zinc oxide and eugenol cement (ZOE) has been widely used in the primary dentition $(1,5)$. Nevertheless, some untoward reactions elicited by these materials have limited their use. These adverse effects include being irritating for the tissues and triggering foreign-body reactions within the periapical tissues, particularly when extruded into the extradental space $(6,7)$. The irritating potential of the zinc oxide

Correspondence: Prof. Dr. Paulo Nelson Filho, Departamento de Clínica Infantil, Odontologia Preventiva e Social, Faculdade de Odontologia de Ribeirão Preto, USP, Avenida do Café, s/n, 14040-904 Ribeirão Preto, SP, Brasil. Tel: +55-16-3602-4099. Fax: +55-16-3633-0999. e-mail: nelson@ forp.usp.br 
and eugenol-based materials is currently attributed to the eugenol. Another shortcoming that has restricted the use of these compounds is their low resorption capacity, due to which zinc oxide and eugenol particles are left within the periapical tissues as the physiological root resorption occurs (5).

Materials containing iodoform in their composition have also been advised for root canal filling in primary teeth (8) because of its antibacterial activity and easy resorption. However, the rapid elimination of iodoform by the organism leaves behind empty spaces inside the root canal, which may undermine the success of the endodontic therapy (1). Additionally, the use of iodine-based materials in contact with live tissues has no longer been indicated because of their potential for causing toxic side-effects (9).

On the other hand, due to its excellent biological properties, calcium hydroxide is one of the most employed medications in Dentistry, particularly in pediatric patients, and has been indicated for a variety of clinical situations, including root canal filling of primary teeth $(4,8)$. Among the beneficial properties of calcium hydroxide are its biocompatibility $(10,11)$, antibacterial activity (12), induction of mineralized tissue formation (13-15), activation of alkaline phosphatase and collagen synthesis (16) and ability to produce hydrolysis of bacterial endotoxin (17).

Reports on the literature show divergent outcomes and there is no consensus related to the best root canal filling material for primary teeth. Recently, Chawla et al. $(4,18)$ described a clinical radiographic evaluation of a mixture of zinc oxide powder and calcium hydroxide for primary tooth obturation. The strategy aimed at using a paste with resorption rate similar to that of physiologic root resorption in primary teeth.

Calen ${ }^{\circledR}$ paste is a commercial calcium hydroxide and polyethylene glycol-based material for use as a root canal dressing, which has recognizably good tissue tolerance $(10,14)$. The properties of Calen paste thickened with zinc oxide as a possible root canal filling material for primary teeth has recently been investigated (12). However, there are no published studies evaluating the biocompatibility of this material.

The aim of this study was to evaluate the histopathological response of apical and periapical tissues of dogs' teeth, after biopulpectomy and root canal filling with the following materials: Calen paste thickened with zinc oxide; paste composed of iodoform, Rifocort ${ }^{\circledR}$ and camphorated paramonochlorophenol; zinc oxide eugenol cement; and sterile saline.

\section{MATERIAL AND METHODS}

All animal procedures performed in this study conformed to protocols reviewed and approved by the Animal Care Committee of the University of São Paulo (Protocol \#02.1.1460.53.0).

The second, third and fourth mandibular premolars and the second and third maxillary premolars of 2 mongrel dogs aged 12 to 18 months and weighing between 8 and $10 \mathrm{~kg}$ were selected for the study, providing 40 roots. The root canals were assigned to 2 experimental groups (Group I and Group II) $(n=12)$ and 2 control groups (Group III and Group IV) $(n=8)$.

In preparation for the clinical procedures, the animals were anesthetized intravenously with $3 \%$ sodium thiopental (30 mg/kg body weight; Thionembutal; Abbot Laboratories, São Paulo, SP, Brazil). After isolation of the teeth with a rubber dam and disinfection of the operative field with $1 \%$ chlorhexidine digluconate, occlusal accesses were opened, and the working length was determined $2 \mathrm{~mm}$ short of the radiographic apex using size $20 \mathrm{~K}$-files (Maillefer, Ballaigues, Switzerland). The root pulp was removed and the root canals were irrigated with a minimal volume of $3.6 \mathrm{~mL}$ of saline at each change of instrument. The apical foramen was enlarged by sequential use of sizes 15 to $25 \mathrm{~K}$-files at the radiographic apex, always with irrigation. Afterwards, the biomechanical preparation was performed to the working length up to a size $70 \mathrm{~K}$-file. A size $25 \mathrm{~K}$-file was then reintroduced into the canals, at the total length of the root, to remove dentin chips or other debris that may have possibly been taken to the apical foramen during instrumentation. After irrigation with saline, the root canals were dried by aspiration and use of sterile paper points, filled with $14.3 \%$ buffered EDTA (pH 7.4) (Odahcan; Herpo Produtos Dentários Ltda., Rio de Janeiro, RJ, Brazil) and left for 3 min, stirring with a K-file. After copious irrigation with saline, the liquid was aspirated, and then canals were dried with sterile paper points.

Since all variables should be evaluated in a same animal and in the different dental quadrants, each hemiarch was alternately subjected to the following experimental protocols:

Group I: Calen paste (S.S.White Artigos Den- 
tários Ltda., Rio de Janeiro, RJ, Brazil; composition: 2.5 g calcium hydroxide, $0.5 \mathrm{~g}$ zinc oxide, $0.05 \mathrm{~g}$ colophony and $1.75 \mathrm{~mL}$ polyethylene glycol 400) thickened with zinc oxide (Biodinâmica Química e Farmacêutica Ltda., Ibiporã, PR, Brazil) (12 root canals). The Calen ${ }^{\circledR}$ paste was thickened by mixing $1.0 \mathrm{~g}$ of the paste with $1.0 \mathrm{~g}$ of zinc oxide on a glass plate. The resulting material was inserted into the canals using a $\mathrm{K}$-file.

Group II: Paste composed of iodoform, Rifocort and camphorated paramonochlorophenol (12 root canals). This paste is prepared with equal parts of the 3 components, which correspond to $0.30 \mathrm{mg}$ iodoform (Probem Ltda., Catanduva, SP, Brazil), 0.25 mg Rifocort $^{\circledR}(5.0 \mathrm{mg}$ prednisolone acetate plus $1.5 \mathrm{mg}$ Rifamycin SV sodium; Medley, Campinas, SP, Brazil) and 0.10 $\mathrm{mL}$ camphorated paramonochlorophenol (Biodinâmica Química e Farmacêutica Ltda.). The resulting paste was inserted into the canals using a $\mathrm{K}$-file.

Group III (control): Zinc oxide-eugenol cement (8 root canals). The zinc oxide-eugenol cement (Biodinâmica Química e Farmacêutica Ltda.) was prepared by mixing $1.0 \mathrm{~g}$ of zinc oxide powder with 10 drops of eugenol. The resulting paste was inserted into the canals using a K-file.

Group IV (control): Sterile saline (8 root canals). The sterile saline (Glicolabor Indústria e Farmacêutica Ltda., São Paulo, SP, Brazil) was stored in glass anesthetic cartridges and inserted into the canals using a cartridge-type Carpule syringe with a disposable 27-gauge long dental needle (BD, Juiz de Fora, MG, Brazil).

Radiographs were taken of all groups after root canal filling to check the quality and extension of the obturation. Thirty days after the surgical procedure, the teeth were reexamined radiographically and the animals were killed by anesthetic overdose. The maxilla and mandible were dissected and sectioned to obtain individual roots. The samples were washed and demineralized with EDTA in a microwave oven (Sharp, São Paulo, SP, Brazil). The roots were then washed in running water for $24 \mathrm{~h}$, dehydrated in increasing concentrations of ethanol, cleared in xylol, and embedded in paraffin blocks. Serial $6-\mu \mathrm{m}$-thick longitudinal sections obtained were stained with hematoxylin and eosin (HE) and Mallory Trichrome. In the histopathological analysis, a descriptive qualitative evaluation was performed. The following parameters were assessed and the subjective quantitative results were classified according to a scoring system as follows: a) intensity of inflammatory infiltrate: score 1, absent, score 2, mild; score 3, moderate; score 4, severe; b) thickness of the periodontal ligament: score 1, normal; score 2, mildly increased, score 3, moderately increased; score 4, severely increased; c) cementum resorption: score 1, absent; score 2, present; d) dentin resorption: score 1, absent; score 2, present; e) bone resorption: score 1, absent; score 2, present. The histopathological analysis was performed by a single examiner who was blinded to the groups.

The results were analyzed statistically by the Mann-Whitney nonparametric test at 5\% significance level using GMC 8.1 software (available from http:// www.forp.usp.br/restauradora/gmc/gmc.html).

\section{RESULTS}

The distribution of specimens according to the scores attributed to the histopathological parameters in each group and group comparison are summarized on Table 1.

Group I (Calen paste thickened with zinc oxide): The apical and periapical regions of the roots in this experimental group were close to normality in 10 of the 12 specimens examined. In the root apex region, the apical cementum lacunae exhibited intact connective tissue, and areas of resorption were not evidenced on the cementum surface. No inflammatory cells were observed in the periodontal ligament of 6 roots, whereas a mild infiltrate of monoclueated inflammatory cells, diffusely scattered, was evident in the periodontal ligament of the other 6 roots. For all specimens in this group, great number of collagen fibers and cells could be noticed. The periodontal ligament was normal in 8 roots, mildly thickened in 3 and moderately thickened in 1 root. Resorption of mineralized tissues (cementum, dentin and bone) was not observed in any specimen (Figs. 1 and 2).

Group II (Iodoform, Rifocort and camphorated paramonochlorophenol-based paste): The histopathological findings of this group revealed that the apical and periapical regions of 9 roots were in the initial stage of an ongoing repair process. Non-repaired areas of resorption could be noticed on the cementum surface of 3 specimens; dentin resorption, however, was not observed in any root. Moderate presence of diffusely scattered monoclueated inflammatory cells, mild edema and reduced number of collagen fibers and cells were evident 
in the periodontal ligament of 4 roots. Mild mononuclear inflammatory infiltrate, with discreet edema and reduced fibrogenesis were evident in 8 roots. Thickness of the periodontal ligament was mildly increased in 3 roots and moderately increased in 9 roots. Extrusion of the filling material to the periapical region occurred in 8 roots and, surrounding the extruded material, few inflammatory cells and collagen fibers could be seen, even though the formation of a complete fibrous capsule was not observed

Table 1. Distribution of specimens according to the scores attributed to the histopathological parameters in each group and group comparison.

\begin{tabular}{|c|c|c|c|c|}
\hline $\begin{array}{l}\text { Histopathological } \\
\text { parameters }\end{array}$ & Group I & Group II & Group III & Group IV \\
\hline \multicolumn{5}{|l|}{ Inflammatory infiltrate } \\
\hline Absent (score 1) & 6 & 0 & 0 & 4 \\
\hline Mild (score 2) & 6 & 8 & 2 & 4 \\
\hline Moderate (score 3 ) & 0 & 4 & 5 & 0 \\
\hline Severe (score 4$)$ & 0 & 0 & 1 & 0 \\
\hline Total number of roots & 12 & 12 & 8 & 8 \\
\hline Statistical analysis & $\mathrm{a}$ & $\mathrm{b}$ & $\mathrm{c}$ & a \\
\hline \multicolumn{5}{|l|}{ Periodontal Ligament } \\
\hline Normal (score 1) & 8 & 0 & 0 & 3 \\
\hline Mildly increased (score 2) & 3 & 3 & 1 & 5 \\
\hline Moderately increased (score 3 ) & 1 & 9 & 5 & 0 \\
\hline Severely increased (score 4) & 0 & 0 & 2 & 0 \\
\hline Total number of roots & 12 & 12 & 8 & 8 \\
\hline Statistical analysis & $\mathrm{a}$ & $\mathrm{b}$ & $\mathrm{c}$ & $\mathrm{a}$ \\
\hline \multicolumn{5}{|l|}{ Cementum resorption } \\
\hline Absent (score 1) & 12 & 9 & 4 & 8 \\
\hline Present (score 2) & 0 & 3 & 4 & 0 \\
\hline Total number of roots & 12 & 12 & 8 & 8 \\
\hline Statistical analysis & $\mathrm{a}$ & $\mathrm{a}$ & $\mathrm{b}$ & a \\
\hline \multicolumn{5}{|l|}{ Dentin resorption } \\
\hline Absent (score 1) & 12 & 12 & 8 & 8 \\
\hline Present (score 2) & 0 & 0 & 0 & 0 \\
\hline Total number of roots & 12 & 12 & 8 & 8 \\
\hline Statistical analysis & $\mathrm{a}$ & $\mathrm{a}$ & $\mathrm{a}$ & $\mathrm{a}$ \\
\hline \multicolumn{5}{|l|}{ Bone resorption } \\
\hline Absent (score 1) & 12 & 4 & 5 & 8 \\
\hline Present (score 2) & 0 & 8 & 3 & 0 \\
\hline Total number of roots & 12 & 12 & 8 & 8 \\
\hline Statistical analysis & $\mathrm{a}$ & $\mathrm{b}$ & $\mathrm{a}$ & $\mathrm{a}$ \\
\hline
\end{tabular}

Different letters indicate statistically significant differences $(\mathrm{p}<0.05)$. in any of the specimens examined. Bone resorption, with the presence of osteoclasts, was noticed in all of these 8 roots, but no evidence of dentin resorption was detected in any specimen (Fig. 3).

Group III (Zinc oxide-eugenol cement): The periapical region of all root canals in this experimental group was altered. Mononucleated and polymorphonucleated inflammatory cells were observed in the apical cementum region, surrounding the filling material at the apical foramen. Areas of cementum resorption were evident in 4 of the 8 roots examined. The periodontal ligament exhibited intense and moderate thickening in 2 and 5 roots, respectively, and was mildly thickened in only 1 root. Noticeable fibrilar dissociation and reduced fibrogenesis, in addition to generalized edema among the inflammatory cells, were observed in this region. The inflammatory infiltrate was of mild degree in 2 roots, moderate in 5 and severe in 1 root, the latter exhibiting both mononucleated and polymorphonucleated cells (mixed type). Dentin resorption was not observed in any of the examined specimens, whereas bone resorption was found in 3 roots (Fig. 4).

Group IV (sterile saline): The events of inflammatory response in this control group were very close to those observed in the specimens of Group I. Likewise, histopathological alterations were not evidenced in the root apex region. The inflammatory cells infiltrate in the periodontal ligament was composed of mononucle- 


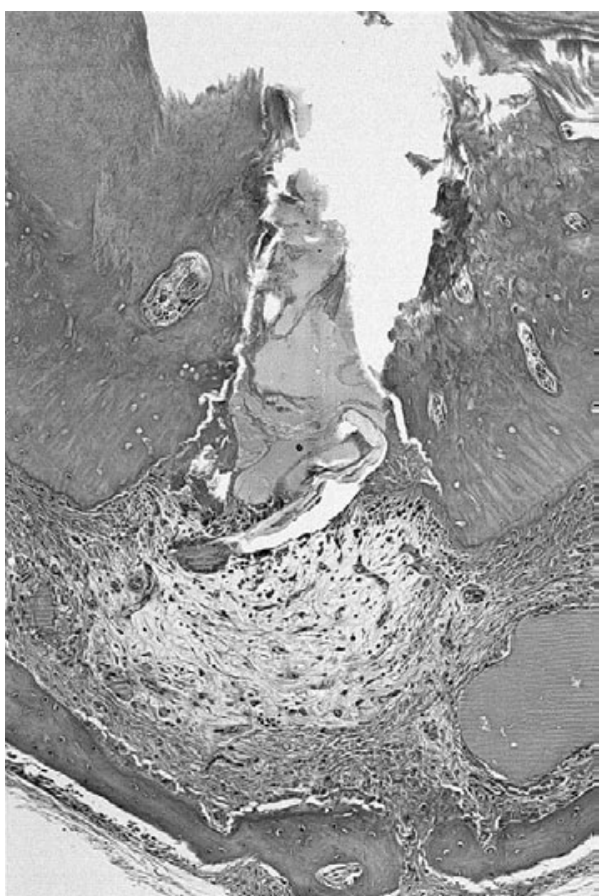

Figure 1. Panoramic view of the root apex and periapical region in Group I, treated with Calen paste thickened with zinc oxide $(\times 24$ magnification).

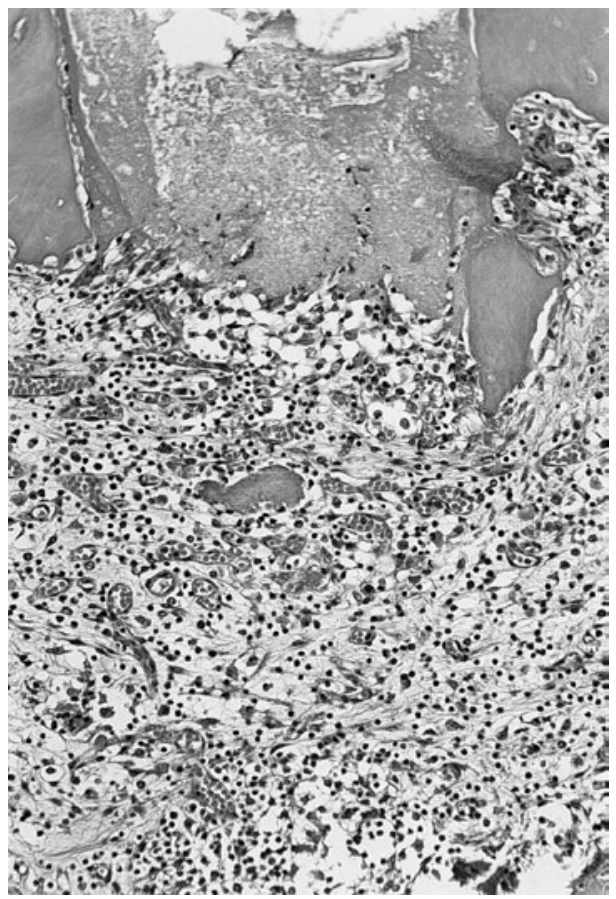

Figure 3. Detail of the periapical region in Group II, treated with the paste composed of iodoform, Rifocort and camphorated paramonochlorophenol, showing inflammatory cells and intense vascular congestion near the material ( $\times 40$ magnification).

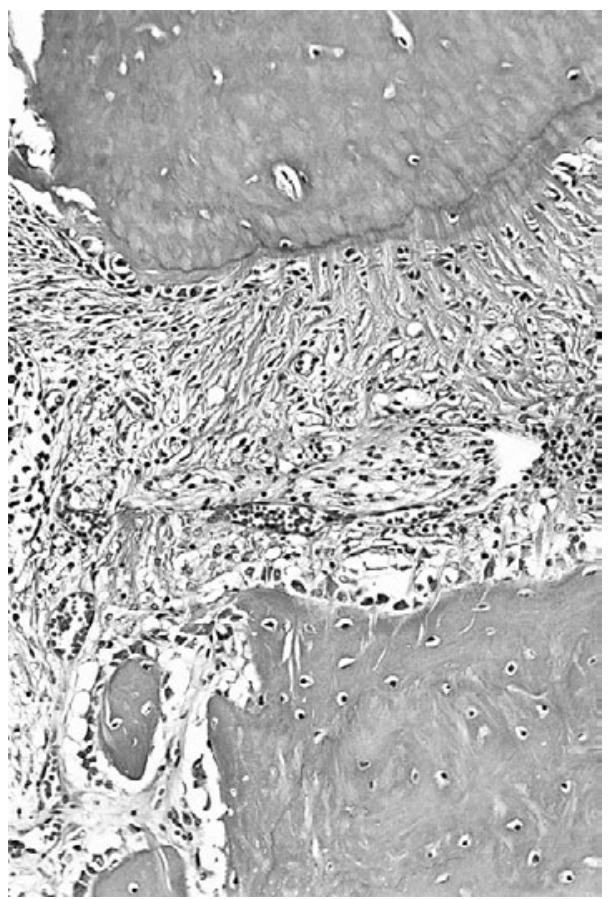

Figure 2. Detail of the periapical region in the group treated with Calen paste thickened with zinc oxide, showing marked presence of collagen fibers disposed in different directions ( $\times 40$ magnification $)$.

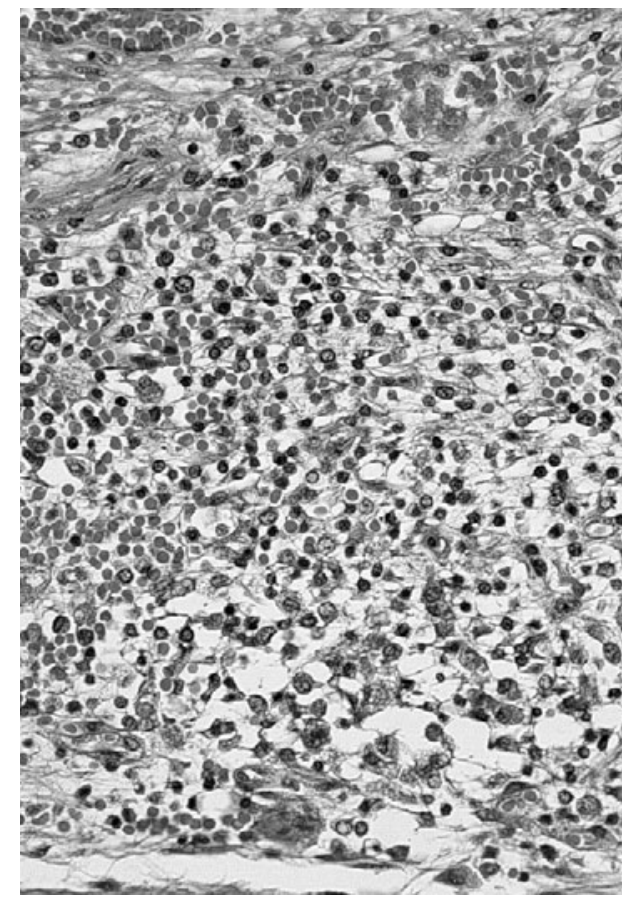

Figure 4. Mononucleated and polymorphonucleated inflammatory cells infiltrate, with intense fibrilar dissociation and areas of edema. Group treated with zinc oxide and eugenol cement $(\times 40$ magnification). 
ated cells and was of mild degree in 4 roots. In other 4 roots, the inflammatory infiltrate was absent. Cells and fibers were observed in all specimens. The thickness of the periodontal ligament was normal in 3 roots and appeared mildly increased in 5 roots. Resorption of mineralized tissues (cementum, dentin and bone) was not observed in any specimen (Fig. 5).

Statistical analysis of the histopathological results could not show differences between Groups I and IV as well as between the Groups II and III ( $p>0.05)$. However, Groups I and IV were statistically different from Groups II and III $(\mathrm{p}<0.05)$.

\section{DISCUSSION}

Calcium hydroxide-based pastes have been indicated for root canal filling in primary teeth due to calcium hydroxide tissue biocompatibility $(10,11,13)$. Chawla et al. (18), in a former study, found clinical success in $100 \%$ of the cases after root canal filling of primary teeth with a calcium hydroxide/zinc oxide-based paste, the material being resorbed in synchrony with the physiological root resorption. Accordingly, Rosendal

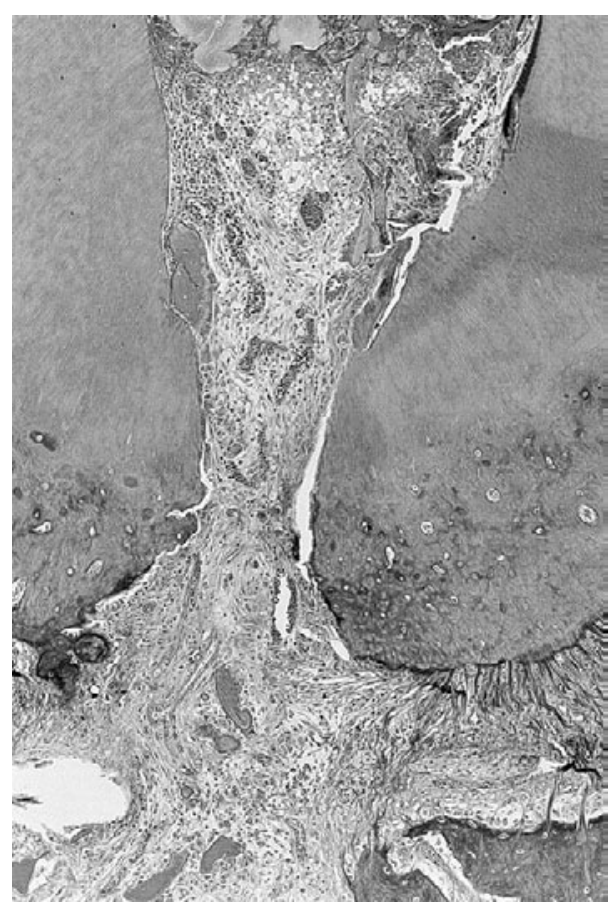

Figure 5. Interstitial tissue and periodontal ligament in an apparently ongoing repair process. Group treated with saline ( $\times 40$ magnification). and Weinert-Grodd (19) have advocated that calcium hydroxide-based pastes may be used as filling materials for primary teeth because they are resorbed concomitantly with the physiological root resorption process.

Nevertheless, is spite of its outstanding biological properties, some physicochemical properties of calcium hydroxide are quite unfavorable, the material being permeable to tissue fluids, resorbable at the periapical region and soluble within the root canals. In the present study, the Calen paste was thickened with zinc oxide to decrease its resorption rate, which should ideally occur simultaneously with the physiological resorption of the primary tooth roots.

The histopathological findings of Group I confirmed the biocompatibility of the Calen paste thickened with zinc oxide and are consistent with the results of previous studies $(10,11,14)$, in which the Calen paste was used without zinc oxide thickening. In spite of presenting high antimicrobial activity (12), it appear to be no published reports investigating the biocompatibility of the Calen paste thickened with zinc oxide. The lack of peer-reviewed scientific data hinders a reliable comparison between the outcomes of this work and those of the previous researches.

The histopathological findings for the specimens filled with the paste composed of iodoform, Rifocort and camphorated paramonochlorophenol disclosed that this paste did not appear favorable to repair, the best biological response being obtained for the experimental group in which the root canals were filled with the calcium hydroxide-based paste. The features in Group II may possibly be attributed to the presence of camphorated paramonochlorophenol, the most cytotoxic component of the paste, which could be responsible for the reduced number of fibers, fibroblasts and vessels observed in the periapical region of the specimens.

Another issue that should be highlighted is the significant occurrence of bone resorption in the specimens of Group II, which may possibly due to the high percentage of material extrusion observed in this group, as a result of the greater flowability of the paste.

The root canals filled with zinc oxide-eugenol cement (Group III) showed an adverse tissue response, which included the presence of inflammatory cells, edema and severely thickened periodontal ligament in the majority of the roots, in addition to cementum and bone resorption in 4 and 3 specimens, respectively. These findings are consistent with those of Woods et 
al. (6) which also reported unfavorable results for zinc oxide-eugenol cement used for endodontic therapy in primary dogs teeth. It may be speculated that these events of inflammatory response would be ascribed to the presence of eugenol (7).

In Group IV, in which the foramens were enlarged and the canals were filled with saline, tissue integrity of the apical and periapical regions was maintained. Mild inflammatory cells infiltrate, periodontal ligament with normal thickness and absent resorption of mineralized tissues were observed, which indicate that the operative technique did not interfere with healing in this region.

In this way, regarding biocompatibility, the outcomes of this study may be summarized as follows: satisfactory for Groups I and IV, intermediate for Group II and unsatisfactory for Group III.

On the basis of the histopathological parameters examined and considering the evaluated materials in dog's teeth, the Calen paste thickened with zinc oxide yielded the best tissue response, being the most indicated material for root canal filling of primary teeth with pulp vitality.

\section{RESUMO}

O objetivo deste estudo foi avaliar a resposta dos tecidos apicais e periapicais de dentes de cães, após obturação dos canais radiculares com diferentes materiais indicados para dentes decíduos. Foram utilizados pré-molares de cães, totalizando 40 raízes que, após pulpectomia e preparo biomecânico, foram divididas em 4 grupos, nos quais os canais radiculares foram obturados com os seguintes materiais: Grupo I - pasta comercial composta de hidróxido de cálcio e polietileno glicol $400\left(\right.$ Calen $\left.^{\circledR}\right)$ espessada com óxido de zinco; Grupo II - pasta composta de iodofórmio, Rifocort ${ }^{\circledR}$ e paramonoclorofenol canforado; Grupo III - cimento de óxido de zinco e eugenol; e Grupo IV - solução salina. Decorridos 30 dias, as peças foram submetidas ao processamento histológico. De acordo com os resultados da análise histopatológica observou-se que nos Grupos I e IV as regiões apical e periapical apresentaram aspecto de normalidade, com grande número de fibras e células e ausência de reabsorção dos tecidos mineralizados. No Grupo II observou-se infiltrado inflamatório e edema leves, com discreta fibrogênese e reabsorção óssea. O Grupo III apresentou alteração na região periapical e ligamento periodontal ampliado, com presença de células inflamatórias e edema. Os resultados obtidos permitiram concluir que a pasta Calen espessada com óxido de zinco apresentou a melhor resposta tecidual, sendo a mais indicada para a obturação de canais radiculares de dentes decíduos com vitalidade pulpar.

\section{ACKNOWLEDGEMENTS}

The authors thank CNPq (Process \#470816/2001-5) for the financial support. This investigation was supported in part by a scholarship from the Brazilian Government Research Funding Agency - CAPES (Coordination of Training of Higher Education Graduate).

\section{REFERENCES}

1. Kubota K, Golden BE, Penugonda B. Root canal filling materials for primary teeth: a review of the literature. J Dent Child 1992;8:225-227.

2. Casas MJ, Layung MA, Kenny DJ, Johnston DH, Judd PL. Outcomes of vital primary incisor ferric sulfate pulpotomy and root canal therapy. J Can Dent Assoc 2004;70:34-38.

3. Carrotte PV, Waterhouse PJ. A clinical guide to endodonticsupdate part 2. Br Dent J 2009;206:133-139.

4. Chawla HS, Setia S, Gupta N, Gauba K, Goyal A. Evaluation of a mixture of zinc oxide, calcium hydroxide, and sodium fluoride as a new root canal filling material for primary teeth. J Indian Soc Pedod Prev Dent 2008;26:53-58.

5. Primosch RE, Ahmadi A, Setzer B, Guelmann M. A retrospective assessment of zinc oxide-eugenol pulpectomies in vital maxillary primary incisors successfully restored with composite resin crowns. Pediatr Dent 2005;27:470-477.

6. Woods RL, Kildea PM, Gabriel SA, Freilich LS. A histologic comparison of Hydron and zinc oxide-eugenol as endodontic filling materials in the primary teeth of dogs. Oral Surg Oral Med Oral Pathol 1984;58:82-93.

7. Ho YC, Huang FM, Chang YC. Mechanisms of cytotoxicity of eugenol in human osteoblastic cells in vitro. Int Endod $\mathrm{J}$ 2006;39:389-393.

8. Cerqueira DF, Mello-Moura AC, Santos EM, Guedes-Pinto AC. Cytotoxicity, histopathological, microbiological and clinical aspects of an endodontic iodoform-based paste used in pediatric dentistry: a review. J Clin Pediatr Dent 2008;32:105-110.

9. Araki K, Hirakawa N, Kosugi T, Higashimoto I, Kakiuchi Y, Nakashima M. Iodoform intoxication: a case report of prolonged consciousness disturbance in a patient with a high plasma iodine level. Fukuoka Igaku Zasshi 2007;98:397-401.

10. Nelson-Filho P, Silva LAB, Leonardo MR, Utrilla LS, Figueiredo F. Connective tissue response to calcium hydroxide-based root canal medicaments. Int Endod J 1999;32:303-311.

11. da Silva RA, Leonardo MR, da Silva LA, de Castro LM, Rosa AL, de Oliveira PT. Effects of the association between a calcium hydroxide paste and $0.4 \%$ chlorhexidine on the development of the osteogenic phenotype in vitro. J Endod 2008;34:1485-1489.

12. Queiroz AM, Nelson-Filho P, Silva LA, Assed S, Silva RA, Ito IY. Antibacterial activity of root canal filling materials for primary teeth: zinc oxide and eugenol cement, Calen paste thickened with zinc oxide, Sealapex and EndoREZ. Braz Dent J 2009;20:290-296.

13. de Souza RS, de Souza V, Holland R, Gomes-Filho JE, Murata SS, Sonoda CK. Effect of calcium hydroxide-based materials on periapical tissue healing and orthodontic root resorption of endodontically treated teeth in dogs. Dent Traumatol 2009;25:213218.

14. Leonardo MR, Hernandez ME, Silva LA, Tanomaru-Filho M. Effect of a calcium hydroxide-based root canal dressing on periapical repair in dogs: a histological study. Oral Surg Oral Med Oral Pathol Oral Radiol Endod 2006;102:680-685.

15. Mizuno M, Banzai Y. Calcium ion release from calcium hydroxide stimulated fibronectin gene expression in dental pulp cells and the differentiation of dental pulp cells to mineralized tissue 
forming cells by fibronectin. Int Endod J 2008;41:933-938.

16. Schroder V. Effects of calcium hydroxide containing pulpcapping agents on pulp cell migration, proliferation and differentiation. J Dent Res 1985;64:541-548.

17. Silva LAB, Silva RAB, Branco LG, Navarro VP, Nelson-Filho P. Quantitative radiographic evaluation of periapical bone resorption in dog's teeth contaminated with bacterial endotoxin (LPS) associated or not with calcium hydroxide. Braz Dent J 2008;19:296-300.
18. Chawla HS, Mathur VP, Gauba K, Goyal A. A mixture of $\mathrm{Ca}(\mathrm{OH})_{2}$ paste and $\mathrm{ZnO}$ powder as a root canal filling material for primary teeth: a preliminary study. J Indian Soc Pedod Prev Dent 2001;19:107-109.

19. Rosendahl R, Weinert-Grodd A. Root canal treatment of primary molars with infected pulps using calcium hydroxide as a root canal filling. J Clin Pediatr Dent 1995;19:255-258.

Accepted March 17, 2010 